\title{
THE STUDY OF THE ANTI-EXUDATIVE ACTIVITY OF DEZAPUR ON THE MODEL OF ACUTE PULMONARY EDEMA IN RATS
}

\author{
O.V.Sevryukov, V.A.Volkovoy, S.V.Kolisnyk, K.M.Sytnik \\ National University of Pharmacy \\ Key words: inflammation; lungs; 1-phenethyl-5, 7-dihydro-1H-pirrolo-[2,3-d] pyrimidine-2,4,6-trion \\ (Dezapur); indomethacin
}

\begin{abstract}
The high anti-exudative action of the test compound has been found in the study of a new substance Dezapur on the model of acute toxic pulmonary edema in rats induced by the intraperitoneal introduction of $6 \%$ ammonium chloride solution in the dose of $400 \mathrm{mg} / \mathrm{kg}$. The use of Dezapur in its effective dose of $10 \mathrm{mg} / \mathrm{kg}$ for 5 days led to decrease in pulmonary edema, the survival of animals (67\%) and delayed time of death of the experimental animals in relation to the control pathology group and compared to Indomethacin, respectively. It has been found that the new substance exceeds the values of the antiexudative activity of the reference drug Indomethacin, has a significant impact on improving the total clinical findings and outcomes. According to the preclinical studies the use of Dezapur significantly reduced the signs of intoxication, resulting in preservation of the lung mass ratio relative to the control pathology group. The substance under research can be considered promising for further study for the purpose of its introduction into medical practice as an anti-inflammatory agent.
\end{abstract}

The issues of creating new drugs with the anti-inflammatory activity and low side effects are of great current interest. It is known that inflammatory processes accompany groups of diseases that are different by their nature. Pulmonary edema is one of the most urgent problems of modern medicine [2,4]. Mortality from pulmonary edema is $60-70 \%$ despite the modern equipment of the best clinics in the world. The etiology of pulmonary edema can be varied. There are several forms of pulmonary edema such as cardiogenic and non-cardiogenic acute lung injury, neurogenic edema and other forms. Acute pulmonary edema rapidly develops and takes a special place by severity of the respiratory function disorders and difficulties in treatment $[7,10,11]$. This pathology is of great interest for researchers in searching new pathogenetically substantiated methods of treatment. The mechanism of the anti-inflammatory action of NSAIDs is oriented to inhibition of the enzyme activity of cyclooxygenase $(\mathrm{COX})$ existing in a living organism in two isoforms - COX-1 (constitutive) and COX-2 (induced). Each isoform has its own functions: the therapeutic effect occurs through inhibition of the COX-2 activity, and the main side effects appear while inhibiting COX-1. The range of side effects of NSAIDs is rather wide, gastrointestinal complications are the most dangerous. When using NSAIDs one should also consider the possibility of interactions with other drugs [3].

The aim of our work was a profound study of the pharmacological action of a new chemical substance under the conditional name of Dezapur, namely identification of its anti-exudative activity on the model of the experimental pulmonary edema in rats.

\section{Materials and Methods}

The study object was a new chemical compound 1-phenethyl-5,7-dihydro-1H-pyrrolo-[2,3-d] pyrimidine2,4,6-trion under the conditional name of Dezapur synthesized at the Department of Organic Chemistry by the associate professor Sytnyk K.M. For a profound study of the anti-exudative activity of Dezapur the model of permeability disturbance of the blood pleural barrier in rats induced by intraperitoneal introduction of $6 \%$ solution of ammonium chloride $\left(\mathrm{NH}_{4} \mathrm{Cl}\right)$ in the dose of 400 $\mathrm{mg} / \mathrm{kg}$ of the animal's weight was used. In the liver, ammonium chloride is hydrolyzed to form urea and hydrochloric acid, which reduces the blood alkaline reserves, leads to acidosis, appearance of hemolysis of red blood cells and methemoglobin. A marked hypoxia develops, it leads to dysfunction of the ventilatory lung capacity and abnormal volume increase of the intervascular fluid in the lungs causing development of the alveolar edema and increased lung mass ratio (LMR). The study of the anti-exudative activity of Dezapur was conducted compared to the reference drug Indomethacin $[8,14,15]$.

In the experiment 24 white male rats weighing $250 \pm 10 \mathrm{~g}$ grown in the vivarium of the Central Research laboratory of the National University of Pharmacy were used. All animals were divided into 4 groups ( 6 animals in each group): group 1 - intact control (IC); group $2-$ control pathology (CP), animals treated with distilled water in the volume of $1 \mathrm{ml}$; group 3 - animals received Dezapur in the effective dose of $10 \mathrm{mg} / \mathrm{kg}$; group $4-$ animals received Indomethacin in the effective dose of $5 \mathrm{mg} / \mathrm{kg}$. The test compound was introduced intragastrically as a water solution stabilized with Tween- 80 for pre- 
The study of the anti-exudative activity of Dezapur compared to Indomethacin, $\mathrm{n}=6(\mathrm{M} \pm \mathrm{m})$

\begin{tabular}{|l|c|c|c|c|}
\hline \multicolumn{1}{|c|}{ Experimental group } & Time of death, min & $\begin{array}{c}\text { Mortality, \% } \\
\text { (Fisher criterion) }\end{array}$ & LMR, \% & AA, \% \\
\hline Intact control & - & - & $0.63 \pm 0.04^{*}$ & - \\
\hline Control pathology & $38.20 \pm 2.82$ & 83 & $1.60 \pm 0.20$ & - \\
\hline Dezapur, $10 \mathrm{mg} / \mathrm{kg}$ & $90.00 \pm 10.00^{*}$ & $33^{*}$ & $0.88 \pm 0.19^{\#}$ & 74 \\
\hline Indomethacin, $5 \mathrm{mg} / \mathrm{kg}$ & $71.67 \pm 3.84^{\# \#}$ & $50^{*}$ & $1.01 \pm 0.14^{* *}$ & 61 \\
\hline
\end{tabular}

Notes: ${ }^{*}-p<0.01$ against the control pathology; ${ }^{* *}-p<0.001$ against the intact control; $\#-p<0.05$ against the control pathology; $\# \#-p<0.01$ against the control pathology; $n-$ is the number of animals in the group.

ventive purpose for 5 days. The last introduction was performed 1 hour before the reproduction of the acute pulmonary edema model [1].

The efficiency of Dezapur and the reference drug was assessed by the following indicators: the animal's survival (\%), the time of death ( $\mathrm{min})$, the lung mass ratio (LMR, \%) and the anti-exudative activity (\%, AA).

The lung mass ratio was calculated by the formula:

$$
L M R=\frac{m}{M} \times 100 \%,
$$

where: $\mathrm{m}-$ is the organ weight, $\mathrm{g} ; \mathrm{M}-$ the animal's body weight, $g$.

The anti-exudative activity $(\%, \mathrm{AA})$ was assessed taking into account the survival rates of animals and the pulmonary edema factor by the formula:

$$
A A=100 \%-\frac{100 \% \cdot\left(L M_{r}-L M_{i}\right)}{L M_{c p}-L M_{i}},
$$

where: $\mathrm{LMR}_{\mathrm{i}}$ - is the lung mass ratio of the intact animals; $\mathrm{LMR}_{\mathrm{cp}}$ - is the lung mass ratio of the control pathology; $\mathrm{LMR}_{\mathrm{r}}$ - is the lung mass ratio of the animals treated with the compound under research.

Clinical observations for development of acidosis included the visual assessment of the animal's behaviour (the excitation time, the presence of convulsions, writhing, etc.) and their mortality. In order to assess the state of the lung tissue in the group of animals that received Dezapur the presence of pathological signs (exudate, alveolar edema, venous stasis) was determined compared to the animals of IC and CP, as well as the reference drug $[2-4,9,12]$.

The work with animals complied with the International Code of Medical Ethics (Venice, 1983), the "European Convention for the Protection of Vertebrate Animals used for Experimental and Other Scientific Purposes" (Strasbourg, 1986), Directive 2010/63/EU of European Parliament and Council on the protection of animals used for scientific purposes $[6,13]$.

The results of the study were processed with a standard software package "Statistica" (Version 8.0) and Excel using Fisher test [5].

\section{Results and Discussion}

During the experiment animals in the IC group were alive, alert and agile. In their autopsy the lung tissue was a little bloody, light pink. The lung mass ratio averaged 0.63 .
In the $\mathrm{CP}$ group in $5 \mathrm{~min}$ after intraperitoneal introduction of the toxicant in rats the pulmonary edema, which manifested in short-term excitement and anxiety, developed; the animals took position on the belly. The frequency and depth of breathing changed: at first, they increased, then decreased; the animals were quiet and inactive. In animals convulsions accompanied with writhings appeared. These data show development of severe hypoxia and acidosis, indicating the diffuse alveolar pulmonary edema [2-4]. In the CP group animals died in the range from $18 \mathrm{~min}$ to $56 \mathrm{~min}$ after introduction of ammonium chloride. The average time of death was $38 \mathrm{~min}$. Asphyxia was recorded in all animals, 5 of 6 animals died, mortality was $83 \%$. Visually after autopsy the lungs of dead animals were increased in size, bloody and with a dark colour, and a pink foam (exudate) was discharged from the trachea. The lung mass ratio averaged 1.60, 2.54, and it exceeded the LMR in IC (Table).

In the group of animals treated with Dezapur in $10 \mathrm{~min}$ after introduction of ammonium chloride only 2 of 6 animals took the lateral position. In the group 2 of 6 animals died, mortality was 33\%: first animal died in $80 \mathrm{~min}$, the second one - in $100 \mathrm{~min}$. There were not intoxication symptoms in one animal during the whole period of observation. Three animals had intoxication in a mild form, and in $40 \mathrm{~min}$ it gradually disappeared in two experimental animals, but the state of the third animal remained critical until the end of the experiment. The average time of death was 90 min after introduction of ammonium chloride. The lungs of the animals survived were not bloody and had a light pink colour. In the dead animals and the animal that survived but was in a serious condition the appearance of the lungs was the same as the appearance of the lungs in the CP group. The lung mass ratio averaged 0.88 ; the anti-exudative activity was $74 \%$.

In the group of animals treated with Indomethacin in 10 min after introduction of the toxicant 2 of 6 animals took the lateral position. In all 3 of 6 animals died in the group, mortality was $50 \%$. In all the animals the symptoms of pulmonary edema developed, in 3 animals the hypoxia symptoms gradually disappeared in $35 \mathrm{~min}$ after introduction, one animal died in $66 \mathrm{~min}$ after beginning of the experiment, two animals - in $77 \mathrm{~min}$. The average time of death after introduction of the toxicant was $71.67 \mathrm{~min}$. The appearance of the lungs was the same as the appearance of the lungs of animals in- 
jected with Dezapur, they were light pink, not swollen or moderately swollen, not bloody. The lung mass ratio was 1.01 ; the anti-exudative activity was $61 \%$.

The research results indicate that the new substance Dezapur in the dose of $10 \mathrm{mg} / \mathrm{kg}$ on the model of the experimental pulmonary edema contributes to the survival of $67 \%$ of the animals, and it is almost twice delay the time of death of the experimental animals compared to the control pathology group (Table).

By its anti-exudative action Dezapur in the dose of $10 \mathrm{mg} / \mathrm{kg}$ showed a high anti-exudative activity (74\%) compared to the reference drug Indomethacin (61\%).

\section{CONCLUSIONS}

1. The intragastric introduction of Dezapur in the dose of $10 \mathrm{mg} / \mathrm{kg}$ contributed to 1.8 times decrease of the lung mass ratio in rats in relation to the control pathology group and 1.1 times decrease compared to the reference drug.

2. Dezapur in its effective dose showed a high antiexudative activity (74\%) compared to the reference drug Indomethacin (61\%).

3. The substance under research can be considered promising for further study for the purpose of its introduction into medical practice as an anti-inflammatory agent.

\section{REFERENCES}

1. Доклінічне дослідження лікарських засобів: Метод. рекоменд. / За ред. О.В.Стефанова. - К.: Авіценна, 2001. - C. 292-306.

2. Кованова В.В. // Фармакол. и токсикол. - 1966. - Т. 29, №3. - С. 287-291.

3. Литвиненко Г.Л., Ларьяновська Ю.Б., Власов С.В. // Експеримент. і клін. медицина. - 2014. - №3 (64). - C. $72-77$.

4. Литвиненко Г.Л., Яковлєва Л.В., Власов С.В. та ін. // Клінічна фармація. - 2015. - Т. 19, №1. - С. 51-55.

5. Методы статистической обработки медииинских данных: Метод. рекоменд. / А.Г.Кочетов, О.В.Лянг, И.В.Жиров и др. - М.: РКНПК, 2012. - 42 с.

6. Резніков О.Г., Соловйов А.І., Стефанов О.В. // Вісник фармакол. і фармаиії. - 2006. - №7. - С. 47-61.

7. Ahrens J., Capelle H.H., Przemeck M. // J. Clin. Anesth. - 2008. - Vol. 20, №2. - P. 129-132.

8. Bramow S., Faber-Rod J., Jacobsen C. et al. // J. Mult. Scler. - 2008. - Vol. 14, №5. - P. 711-715.

9. Carvalho L., Carneiro R., Freire E. et al. // J. Rev. Port. Cardiol. - 2008. - Vol. 27, №2. - P. 191-199.

10. Dellacà R.L., Zannin E., Sancini G. et al. // J. Respir. Res. - 2008. - Vol. 12, №9. - P. 51.

11. Díaz N.R., Silva G.D. // J. Rev. Med. Chil. - 2008. - Vol. 136, №3. - P. 356-358.

12. Di Marco F., Tresoldi S., Maggiolini S. et al. // J. Anaesth. Intensive Care. -2008. - Vol. 36, №3. - P. 351-359.

13. Europen convention for the protection of vertebrate animals used for experimental and other scientific purposes. - Council of Europe. Strasburg, 1986. - №123. - P. 52.

14. Mattu A., Martinez J.P., Kelly B.S. // Emerg. Med. Clin. North. Am. - 2005. - Vol. 23, №4. - P. 1105-1125.

15. Richalet J.P., Chenivesse C., Larmignat P. et al. // High. Alt. Med. Biol. - 2008. - Vol. 9, №2. - P. 179-181.

ДОСЛІДЖЕННЯ АНТИЕКСУДАТИВНОЇ АКТИВНОСТІ ДЕЗАПУРУ НА МОДЕЛІ ГОСТРОГО НАБРЯКУ ЛЕГЕНІВ У ЩУРІВ

О.В.Севрюков, В.А.Волковой, С.В.Колісник, К.М.Ситнік

Ключові слова: запалення; легені; 1-френетил-5,7-дигідро-1Н-піроло-[2,3-d]піримідин-

2,4,6-трион (Дезапур); індометацин

При дослідженні 1-френетил-5,7-дигідро-1Н-піроло-[2,3-d]піримідин-2,4,6-триону (Дезапур) на моделі гострого токсичного набряку легенів у щурів, який викликали внутрішньоочеревинним введенням 6\% розчину амонію хлориду у дозі 400 ме/ке, встановлено високу антиексудативну дію зазначеної сполуки. Застосування Дезапуру в ефективній дозі 10 мг/кг протягом 5-ти денного терміну приводило до зменшення набряку легенів, збільшення виживаності тварин (67\%) та відкладеного часу їх загибелі відповідно до групи контрольної патології та в порівнянні з індометацином. Встановлено, що Дезапур перевершує показники антиексудативної активності препарату порівняння індометацину, чинить вагомий вплив на поліпшення загальної клінічної картини і результати лікування. За даними доклінічних спостережень застосування Дезапуру значно зменшило ознаки інтоксикації, привело до збереження масових коефріцієнтів легенів відносно групи контрольної патології. Досліджувану субстанцію можна вважати перспективною для подальшого вивчення з метою впровадження у медичну практику в якості протизапального засобу. 


\section{ИССЛЕДОВАНИЕ АНТИЭКССУДАТИВНОЙ АКТИВНОСТИ ДЕЗАПУРА НА МОДЕЛИ ОСТРОГО ОТЕКА ЛЕГКОГО У КРЫС А.В.Севрюков, В.А.Волковой, С.В.Колесник, К.М.Сытник \\ Ключевые слова: воспаление; легкие; 1-фенетил-5,7-дигидро-1Н-пирроло-}

[2,3-d]пиримидин-2, 4,6-трион (Дезапур); индометацин

При исследовании 1-френетил-5, 7-дигидро-1Н-пирроло-[2, 3-d]пиримидин-2, 4,6-триона (Дезапур) на модели острого токсического отека легких у крыс, который вызывали внутрибрюшинным введением 6\% раствора аммония хлорида в дозе 400 мг/ке, установлено высокое антиэкссудативное действие исследуемого соединения. Использование Дезапура в эфрфективной дозе 10 мг/ка на протяжении 5-дневного срока введения приводило к уменьшению отека легких, выживанию животных (67\%) и отсроченному времени гибели подопытных животных соответственно к группе контрольной патологии и в сравнении с индометацином. Установлено, что новая субстанция превышает показатели антиэкссудативной активности препарата сравнения индометацина, имеет высокое влияние на улучшение общей клинической картины и результаты лечения. По данным доклинических исследований применение Дезапура значительно уменьшило признаки интоксикации, привело к сохранению массового коэфффициента легких относительно группы контрольной патологии. Исследуемое вещество можно считать перспективным для дальнейшего изучения с целью внедрения в медицинскую практику в качестве противовоспалительного средства. 